\title{
A TANUlást TÁMOGATó ÉRTÉKELÉS A PEDAGÓGUSKÉPZÉSBEN
}

\section{RAPOS NóRA}

\author{
az ELTE PPK Neveléstudományi Intézetének \\ adjunktusa \\ rapos.nora@ppk.elte.hu
}

\begin{abstract}
„Ahogy tanulóknak is szükségük van arra, hogy a tanulást magukénak érezzék, úgy a tanárok is el fogják vesziteni a szakmai fejlödésük iránti motivációt, ha nem vonják be öket azon mutatók meghatározásába, amelyeknek a felhasználásával megállapitják szakmai kvalitásukat." Az Európai Tanárképzők Egyesületének a tanárképzés megújitása kapcsán tett ajánlásában megfogalmazott irányelv ráirányítja a figyelmet, hogy miért kell a fejlesztő értékelés szerepével foglalkozni a pedagógusképzésben. A tanulmányban arra találhatók szempontok, hogy miként lehet e fejlesztést elkezdeni.
\end{abstract}

Ha az elmúlt években, de különösen a legutóbbi szabályozásban lezajlott változásokra gondolunk a hazai pedagógusképzésben, akkor számos komoly újdonságot említhetünk. A tanárképzés mesterszintre került, miközben átalakult a képzés neve (tanári szak), a megszerezhető végzettségek száma és rendszere is. A hatályos szabályozás alapján (15/2006. 4. sz. melléklet) részben kompetenciák formájában határozzák meg a kimeneti követelményeket, és ezzel párhuzamosan az akkreditációs eljárás során a képzésben egyes képzőintézmények esetében új tartalmi elemek jelentek meg a mesterségbeli tudás terén. A szakmai gyakorlat megszerzésének lehetősége egy hosszabb gyakornoki félévvel bővül a képzés végén, s mindezekkel párhuzamosan az értékelés rendszerében is megjelennek új elemek, így például az értékelési portfólió alkalmazásnak lehetősége a szakzárásban.

A változások egy koherens rendszerként is értelmezhetők, amelyeknek alapvető célja, hogy a leendő tanár megfeleljen a globális társadalmi változásokból következő új szerepelvárásoknak (Golnhofer, 2007; Kálmán és Rapos, 2007). A társadalmi változásokkal párhuzamosan tudományos igényü vizsgálatok sora is bizonyítja, hogy a pedagógusképzés megújítását kiemelt feladatként kell kezelni. Azokat az új törekvéseket, amelyeknek középpontjában a ma hatékonynak vélt tanár leírása áll, számtalan kutatási előzménnyel lehetne illusztrálni (például: Ayers et al.,2000; Lingard et al.,2002; Gustafson 2003; OECD, 2003; OECD, 2005; ATEE, 2006). Egy egyszerủ megfogalmazás szerint az a hatékony tanár, aki különböző területeken is kompetens. Bár a vélemények a fenti kérdésben szerteágazóak, megegyeznek azonban abban, hogy sok, ha ugyan nem a legtöbb, jellemzöje a sikeres tanárnak 
csak akkor válik nyilvánvalóvá, ha már elkezdett tanítani. Mindez a tanárképzés rendszerének megfogalmazásában is jelentős szempont, hiszen ez vezet el ahhoz a gondolathoz, miszerint a képzés csak egy része a tanárrá válás folyamatának (Nagy, 2004). Az újfajta helyzetben csak a tanulók, a pedagógustársak és saját maga tanulását támogatni tudó pedagógus képes megfelelni. Ennek elérésében komoly szerepe van a tanulást támogató értékelésnek.

A fentieket figyelembe véve a tanulmányban röviden áttekintjük a fejlesztő, vagy tanulást támogató értékelés elméleti kereteit, majd kísérletet teszünk a pedagógusképzéshez kötődő vetületeinek tisztázására, s néhány jó gyakorlat bemutatására. Szólunk a képzésen belüli értékelési gyakorlat átalakításnak, újraértelmezéseinek alternatíváiról, majd a tanári életpályához kötődően elemezzük a fejlesztő értékelés lehetőségeit.

\section{A tanulást támogató értékelés fogalmi keretei}

A fejlesztő értékelés definiálása korántsem egyszerü feladat, de mindenképp lényegi kérdés (például: Black és William, 1998a,b; Vidakovich, 2005; Bognár, 2006; Lénárd és Rapos, 2009). Részben azért, mert még nem egységes a szakmai álláspont e terminus kapcsán, hiszen egyes megfontolások szerint a fejlesztő értékelés azonosítható a formatív értékeléssel. Talán Vidákovich Tibor egyik megfogalmazása mutat rá legmarkánsabban a dilemma lényegére. „A pedagógiai értékelés alapfunkcióinak (szummatív, formatív, diagnosztikus) rendszere, mintegy negyven éve ismert, s viszonylag jól definiált, ennek ellenére időröl-időre újraélednek a rendszert elemző, az egyes funkciók müködést, hatásait vizsgáló kutatások, illetve egyik, vagy másik értékelési funkció alkalmazási körét kiterjesztő, új lehetőségeket kereső kísérletek...Hasonló jelenségnek lehetünk tanúi a kilencvenes évek közepétől a fejlesztő értékeléssel kapcsolatban. A régóta ismert, de a másik két értékelési funkcióhoz képest ritkábban elemzett és az iskolai gyakorlatban ugyan rendszeresen, de a szükségesnél kevésbé tudatosan alkalmazott formativ értékelést újradefiniáló, alkalmazásainak körét jelentösen kiszélesitö, kezdetben föleg angol nyelvterületen zajló kutatások ma már világszerte ismertek..." (Vidákovich, 2005).

$\mathrm{Az}$,új paradigmát vallók” szerint a fejlesztő értékelés arra szolgál, hogy megállapítsa a tanuló fejődését, értelmezze tanulási szükségleteit és ehhez ,igazítsa” a tanulást; lényege a fejlödés támogatása, az önértékelés, az énkép, a metakogníció fejlesztése, támogatása. A fejlesztő értékelés ebben a megközelítésben tehát nem azonos egy szüken értelmezett formatív értékeléssel, mert fókusza a fejlödés folyamatán van, s elsődlegesen nem a külső célok megvalósításán.

A definiálási bizonytalanságot kezdetben az angol szakkifejezések sem segítették, majd azok differenciálódása után a magyar szóhasználat is sokáig elfedte a formatív (formative assessment) és fejlesztő értékelés (assessment for learning) közti 
eltérö megközelítés lényegét ${ }^{1}$. Az angliai Assessment Reform Group ${ }^{2}$ kilencvenes években indult munkájának köszönhetően mára árnyaltabb a pedagógiai szakkifejezések alkalmazása is. Az említett csoport fejlesztései több kérdéskör mentén zajlottak, de középpontban a következő a kérdés állt: Vajon növeli-e a tanulói teljesítményeket, akár teszteredményeiket is a formativ értékelés fejlesztése, meghonositása a pedagógiai gyakorlatban. S bár a pedagógiai szaksajtóban a tesztek veszélyeit is kommunikálták, a csoport egyik fö feladatává vált e kérdés vizsgálata és megoldási javaslatok kidolgozása. Paul Black és William Dylan „Értékelés és tanulás az osztályteremben" (Assessment and Classroom Learning) című elméleti munkája (Black és William, 1998a), majd az ezt követö, igen nagyhatású „A fekete dobozon belül: sztenderdek növelése az osztálytermi értékelés segítségével" (Inside the black box: Raising Standards Through Classroom Assessment) címet viselő kutatási beszámolójuk (Black és William, 1998b) indította el a formatív értékelés elemzőbb és átfogóbb vizsgálatára irányuló munkálatokat. Ezeknek eredményei számos publikációban és módszertani kiadványban kaptak nyilvánosságot. Mindennek során az elemző és értelmező folyamatnak részeként kezdték alkalmazni a formatív értékelés helyett a tanulást támogató értékelés (assessment for learning) és a tanulás eredményének értékelése (assessment of learning) kifejezéseket.

A meglevő szakmai problémák ellenére már széles körben elfogadott az OECD definíciója, amely szerint: „a fejlesztő értékelés a tanulók fejlődésének és tudásának gyakori, interaktív módon történő értékelését jelenti, célja a tanulási célok meghatározása és a tanítás azokhoz igazítása" (OECD CERI, 2005). E meghatározásban egyértelmúen ott rejlenek azonban az Assessment Reform Group által 1999-ben kidolgozott a fejlesztő értékelés jellemzésére szolgáló szempontok:

- az értékelési gyakorlatban meghatározóak a tanítás-tanulásról vallott nézetek,

- lényeges a tanulók bevonása a tanulási célok meghatározásába,

- támogatni kell a diákokat, hogy megismerjék és megértsék a követelményeket, ezzel is segítve, hogy azok az ő céljaikká is váljanak,

- a diákokat ösztönözni kell az önértékelésre,

- rendszeresen kell visszajelzéseket adni, amelyek ráirányítják a tanulók figyelmét a továbblépés lehetséges formáira,

- a diákokat meg kell erősíteni abban, hogy mindenki képes a fejlődésre,

- a visszajelzés, reflektálás alapvető az értékelés folyamatában a tanárok és a diákok részéről egyaránt (Black és William, 1999).

\footnotetext{
${ }^{1}$ Az értékelés értelmezésével, funkciójával a kötet több szerzője is foglalkozik, oktatáspolitikai elemzését lásd Halász Gábor tanulmányában.

${ }^{2}$ Assessment Reform Group: http://www.assessment-reform-group.org/
} 


\section{A tanulást támogató értékelés szerepe és lehetőségei a tanárrá válás folyamatában}

A pedagógusképzéssel foglalkozó nemzetközi és hazai szakirodalom szinte már evidenciaként kezeli, hogy a tanárrá válás folyamata nem a képző intézményekben kezdődik és nem ott ér véget. Eszerint a tanári szakma, a tanári karrier egy élethosszig tartó folyamat, amelyben a képzés egyetlen rendszerelem csupán. Ez a szellemiség a pedagógusképzés (initial teacher education), a pályakezdés (induction) és a szakmai továbbfejlődés (professional development) hármasának tudatosabb összekapcsolását igényli. Mégis gyakorta tapasztalható, hogy a pályát kezdő vagy a pályán levő pedagógusok befejezettnek látják képzésüket, és szakmai fejlődésüket is lezártnak tekintik. Ennek oka részben saját iskolai életútjukban rejlik, ahol ritkán késztették őket építö önértékelésre, reflexióra, tudatos tervezésre, vagy saját tanulási folyamatukhoz kötött felelősségvállalásra, értékelésre. Az említett hiányosságok csökkenthetők lennének, ha a fejlesztő értékelés szerepét és lehetőségeit tematikusan és rendszerezetten érvényesítik a pedagógussá válás teljes folyamata során.

\section{Lehetöségek az egyetemi/föiskolai képzésen belül}

Az első lépések mindenképp a képző intézményekben tehetők. Két ponton is vizsgálhatjuk a fejlesztő értékelés alkalmazásból fakadó kihívásokat: a képzési tartalomban, az alkalmazott értékelési eljárásokban, s a képzés részeként megjelenő gyakorlat kapcsán. Mindkét szempont mentén történő elemzés lehetne egy-egy tanulmány tárgya, itt csupán a fejlesztő értékeléshez kötődően emeljük ki a tartalom szintjén a nézetek, a tapasztalatok szerepét, $\mathrm{s}$ a különféle módszerekben rejlő alternatívákat, valamint a gyakorlat kapcsán a mentorálás és sztenderdek néhány kérdését.

Tartalmi megfontolások és a fejlesztő értékelés

Korábbi kutatások igazolták, hogy az önelemző gondolkodás minősége, érvényesítése és a tanítás sikeressége összefügg egymással (Richardson, 1997, idézi Falus, 2006; Holt és Reynolds, 2000, idézi Falus, 2006). A reflektív gondolkodás már a képzés során szürőként funkcionál, hiszen a hallgatók saját, előzetes elképzelései és tapasztalatai nagymértékben meghatározzák, hogy mit fogadnak el, mit tartanak fontosnak és mit vallanak majd magukénak a képzés alatt tanultakból. Ezt nem lehet figyelmen kívül hagyni a tanárképzésben, így az előzetes tapasztalatok elemzéséből, értékeléséből érdemes kiindulni. A mesterségre készülő tanárjelölt általában ritkán él az önelemzés gyakorlatával, vagy nézeteinek, gondolatainak tudatosításával. Elgondolásait, felkészülését nem befolyásolják érdemben az ellenőrzésértékelés reflexiói. Ezért elengedhetetlen, hogy a képzés elején és aztán annak további szerves részeként megjelenjenek ilyen célú kurzusok vagy feladatok. 
A hazai pedagógusképzésben különféle formában meg is jelentek, jelennek az önelemzést segítő kurzusok, amelyeknek fogadtatásáról még nincs átfogó képünk ${ }^{3}$, de példaként tanulságos egy, a „Pedagógiai tapasztalatok, nézetek elemzése” címü kurzus kapcsán megfogalmazott hallgatói vélemény:

„....Mankót kaptam arra nézve, hogy nem elég elhivatottnak lenni, hanem néha le kell ülni, és számba venni a „Miért?-eket és a „Hogyan?-okat. Nemcsak ilyenkor, amikor reményteli terveket szövögetek arról, hogy milyen tanár leszek, nemcsak akkor, amikor még kezdeti lelkesedéstôl fütött kezdö pedagógusként hiszek a szakma hatalmában, hanem késöbb is, pályafutásom alatt újra és újra."

„.... a kurzus rávilágitott, hogy tanáraim milyen mély nyomokat hagytak bennem, de elkezdtek ébredezni saját gondolataim is, mert olyan kérdéseken kellett elgondolkodjak, amelyeken még korábban nem..."

Az önértékelés, önelemzés gyakorlatának kialakításában jelentőse szerepe van a nézetek elemzésének, ahol a leendő pedagógus tudatosíthatja saját nézeteinek meglétét, megértheti azok szerepét és szembesülhet más, az övétől gyökeresen eltérő elképzelésekkel. Egy ilyen folyamatban való részvétel megkívánja a fejlesztő értékelés jelenlétét önértékelés és önelemzés formájában, a tanártól és társaktól érkező visszajelzések, továbbgondolást segítő szempontok mentén is.

Mielőtt a fejlesztő értékelés során alkalmazott módszerekről szólnék, nézzük meg, hogy miként illeszthetők be azok az új pedagógusképzési struktúra egészébe. A bevezetőben utaltunk arra, hogy a hatályos szabályozásban (15/2006. 4. sz. melléklet) részben kompetenciák formájában határozzák meg a pedagógusképzés kimeneti, képesítési követelményeit ${ }^{4}$. Ideális esetben egy, a képzés végén álló hallgató saját szakmai kompetenciáinak ismeretében fogalmazhatja meg szakmai profilját - e fogalomról lásd később - pályakezdésekor, úgy, hogy összehasonlítja a képesítési követelményekkel. Ha Falus Iván (2005) összegzése alapján elfogadjuk, hogy a képesítési követelmények lényegi tulajdonsága az, hogy mérhetőek, akkor jól érzékelhető feladattal állnak szemben a képzőintézmények.

A szakmai profil megfogalmazásáig azonban hosszú fejlesztő út vezet. Kiindulópontként érdemes felidézni, hogy Black és William (1999) a fejlesztő értékelés tartalmi jegyeinek meghatározásakor lényeges sajátosságként emelte ki a tanulók bevonását a tanulási célok meghatározásába. Erre figyelve megfogalmazható, hogy kiemelt feladatként kell kezelni a szakmai követelmények megismertetését és megértését a pedagógusképzés teljes folyamatában. Ennek az evidenciaszerü elvárás-

\footnotetext{
${ }^{3} \mathrm{Az}$ új rendszerü pedagógusképzésre vonatkozik az észrevétel, s nem érinti a régebbi képzés ilyen jellegü, föként személyekhez, intézményekhez kötődő törekvéseit, gyakorlatát.

${ }_{4}^{4}$ Jelen tanulmányban nem érintjük a szabályozásban felsorolt követelmények tartalmi elemzését.
} 
nak egyik útja lehetne - hagyományosan - a tematikákban szereplő fejlesztési célok vagy fejlesztendö kompetenciák közös értelmezése, s az értékelésben való tudatos és formális megjelenitése. Megvalósítására többféle módszert, eszközt lehet alkalmazni, például: fejlődési terv, T-kártya, portfólió.

A fejlődési terv középpontjában az egyén, jelen esetben a pedagógusjelölt, fejlődési folyamatának tudatos és önmaga által megfogalmazott, rendszerezett és konkrét cselekvésbe ágyazott terve áll. A terv alapja minden esetben egy diagnózis és egy erre épülő cselekvési terv. Ezeknek fókusza a pedagógusképzés kapcsán a jelölt pedagógussá válásnak folyamata és az ehhez szükséges kompetenciák felmérése, majd fejlesztése. Bár a fejlődési terv a hallgató által készített dokumentum, elkészítést szakmai közremüködőknek (szemináriumot vezető tanár, mentor, gyakorlatvezető tanár) folyamatosan támogatni kell, hiszen a fejlődés „útvonala”, tempója nagyon egyedi lehet. Épp ez az, ami képzők számára is fokozottabb kihívást jelent, hisz adott tanegységen belül különböző kompetenciák fejlesztést is támogatni kell.

A T-kártya alapkérdése, a közös fejlesztési célok és az azokhoz tartozó értékelési szempontok kialakítása. Emellett valódi bevonódást biztosít a szempontok megfogalmazása, a közös nyelv és megállapodás kialakításához. A T-kártya a formájáról kapta a nevét, kialakításnak menete a következő lehet:

- Először megfogalmazzuk azt a tevékenységet, produktumot, amire az értékelés irányulni fog. Például: Mitől jó egy pedagógiai esszé? Vagy: Mitől jó egy megfigyelési jegyzőkönyv elemzése? Majd a hallgatók ötletrohamban vagy pármunkában összegyüjtik, hogy ők mire figyelnének.

- Ezután közös megbeszélés, értelmezés következik, miközben a hallgatók az általuk felírt szempontokat megmutatják csoporttársaiknak is. Természetesen a pedagógus kiegészítheti saját szempontjaival a listát, miközben ezt megmagyarázza diákjainak.

- Következik a rendszerezés, vagyis a nagyobb kategóriák megalkotása, amelyek alkalmasak lesznek arra, hogy a diákok által megnevezett szempontokat összegezzék, csoportosítsák.

- Végül T alakú formába rendezik a közösen kialakított kategóriákat, s a hozzájuk tartozó szempontokat, újra értelmezve, esetleg a megfogalmazást pontosítva, megbeszélve a tartalmukat. A T vízszintes vonala maga a téma, balra a nagyobb kategóriák, jobbra az azokat leíró szempontok (három-öt) kerülnek.

Álljon itt példaként egy pedagógiai szemináriumon elkészített, minden hallgató által elfogadott és átgondolt T-kártya, a félév végén leadásra kerülő szemináriumi dolgozat értékelési szempontjairól. (Lásd 1. táblázat) 
1. táblázat: T-kártya, értékelési szempontok

\begin{tabular}{|c|c|}
\hline $\begin{array}{c}\text { Az elemzö dolgozat } \\
\text { szempontjai }\end{array}$ & Részletezés \\
\hline $\begin{array}{l}\text { Formai } \\
\text { megoldások }\end{array}$ & $\begin{array}{ll}\text { - } & \text { formai szerkesztettség, tagolás; } \\
\text { - } & \text { egységes, szakszerüen alkalmazott hivatkozási rendszer } \\
& \text { dolgozaton belül; } \\
\text { - } & \text { világos stílus, szakszerü megfogalmazás; } \\
\text { - } & 10-12 \text { oldal; } \\
\text { - } & \text { legyen szemlélttetés, ahol szükséges legyen ábra, táblázat; } \\
\text { - } & \text { az ábráknak, táblázatoknak legyen számozása, címe; }\end{array}$ \\
\hline $\begin{array}{l}\text { A téma } \\
\text { feldolgozása }\end{array}$ & $\begin{array}{l}\text { - } \quad \text { koherens, lényegre törő; } \\
\text { - } \quad \text { téma és a dolgozat tatalma függjön össze; } \\
\text { - } \quad \text { a dolgógos problémamegfogal koncepciójának és szerkezetének bemutatása; }\end{array}$ \\
\hline $\begin{array}{l}\text { Szakirodalom és } \\
\text { feldolgozása }\end{array}$ & $\begin{array}{l}\text { - } \quad \text { tükröződjön az, hogy a szerző megértette az olvasottakat; } \\
\text { - } \quad \text { megfelelő szakmai forrás legyen; } \\
\text { az elemzett tanulmányok álláspontjának precíz } \\
\text { - } \quad \text { ponfogalmazása jellemezze; } \\
\text { - } \quad \text { a szakirodalomhasználat, azok szakszzerủ magyarázata; } \\
\text { (nem átvétel); }\end{array}$ \\
\hline $\begin{array}{l}\text { Személyes } \\
\text { vélemény } \\
\text { megfogalmazása }\end{array}$ & $\begin{array}{ll}\text { - } & \text { következetés, problémamegfogalmazása; } \\
\text { - } & \text { elmélet - gyakorlat kapcsolatának megmutatása; } \\
\text { - } & \text { önálló elemzési szempont kialakítása; } \\
\text { - } & \text { személyes tapasztalatok elemző feldolgozása. } \\
\end{array}$ \\
\hline
\end{tabular}

A T-kártyánál átfogóbb, komplexebb lehetőség a portfólió, a hallgatók munkáiból összeállitott célirányos gyüjtemény, amely bemutatja készítőjének erőfeszítéseit, fejlődését és eredményeit egy vagy több területen. A portfólió több formája különíthető el (Falus és Kimmel, 2009; Lénárd és Rapos, 2009). A tanárképzés kapcsán érdemes számba venni a fejlődést dokumentáló és az értékelési célú portfóliót is. A portfólió alkalmazása a képzés teljes folyamata során ajánlott. A fejlődést dokumentáló portfólióban folyamatosan és tudatosan megjeleníthetők az elérendő kompetenciák és az azok érdekében megtett folyamat, valamint annak eredményei. $A z$ értékelö portfólió alkalmazása is lehetséges a szakzárás részeként, ahol a cél, hogy a tanári képesítővizsga során a jelölt az önmaga által összeállított portfóliója segítségével igazolja a tanári pályához szükséges készségeit és képességeit, kompetenciáit. Speciálisan a pedagógusképzéshez kötötten is jelentek meg már ajánlások egy 
ilyen értékelő portfólióra nézve. E javaslat alapján „,a jelöltnek az egyetemi tanulmányaihoz kötődő produktumait kell újra áttekintenie, abból a szempontból, hogy a tanári kompetenciáit igazoló, minőségi munkáit gyüjtse össze. A dokumentumok kiválogatásában a tanárjelölteket támogatják az utolsó féléves gyakorlatot kísérő szemináriumok vezetöi, a vezető tanárok és a mentorok..." (Lénárd, 2009)

Az értékelő portfólió tartalmára pedig a következő ajánlást tették:

- A hallgatónak a tanulmányai során, a különféle tantárgyakhoz kötödően elkészitett munkái (szaktudományi, pszichológiai, pedagógiai, szakmódszertani), például:

○ esszé, szemináriumi dolgozat,

- kutatási beszámoló,

○ óralátogatási jegyzőkönyvek,

- tananyagfejlesztés stb.

- A hallgató iskolai munkája, tanitási gyakorlata során készitett dokumentumai:

○ óravázlatok, tématervek, programcsomagok, projekt leírások;

- a tanításhoz készített segédanyagok (program, szemléltető eszköz, makett);

- feladatbank, dolgozatok;

○ az IKT eszközök tanuló használatának bemutatása (digitális tábla, honlap, e-learning, távoktatás stb.);

- a tanítási óra audio- vagy videofelvétele;

- saját tanítványainak munkái; stb.

- A hallgató reflexiója saját munkájára:

- a jelölt tanári céljainak megfogalmazása;

○ a dokumentumokhoz füzött megjegyzései, magyarázatai, reflexiói.

- a reflexió tipikus elemei: a dilemma; a probléma felismerése, azonositása, definiálása; a dilemma lebontása, elemzése, megoldási-következtetési módok megfogalmazása; az optimális válasza kiválasztása és indoklása." (Lénárd, 2009)

Talán az alábbi végzős tanár szakos hallgató értékelési portfóliójából származó példa jó érzékelteti, hogy milyen komplex, tudatos gondolkodást, önreflexiót eredményezhet a portfólió készítése: „, Sok szakdidaktikai szakirodalmat kell olvasnom, sok kolléga óráját szeretném látogatni, hogy a ,szaktudományi, szaktárgyi és tantervi tudás integrálása” és a „pedagógiai folyamat tervezése” névvel illetett kompetenciacsoportok (Falus, 2006) sztenderdjeinek eleget tegyek. Most még nem látom át, milyen sorrendben érdemes például a nyelvtani részeknek egymásra következniük, még nem érzem, milyen tempóban kell haladnunk, milyen ütemben kell fejlödniük nagyjából a gyerekeimnek (hiszen ez egyénfüggö). Még nem tudok elég jól magyarázni, nem mindig érzem, mit nem ért a tanitványom, hol akad meg és azon hogyan segitsek, hogyan világitsam meg jobban a problémát, még nincsen 
több magyarázati alternatívám. Még nincs tapasztalatom arra vonatkozólag, milyen típusú magyarázatok érthetöbbek, emészthetöbbek. Ezeknek a sztenderdeknek az esetében sokszor nincs meg a kellö tudásom, nézeteim tisztázatlanok, képességeim kialakulatlanok...Mint már emlitettem, az aktiv tanulás fejlesztéséhez még nem rendelkezem sem kellö tapasztalattal, sem a megfelelö módszertani kultúrával. Szeretném megtanulni, hogyan engedjem tanitványaimat fokozatosan szabadjára, hogyan biztositsak számukra egyre nagyobb tanulási autonómiát és szabadságot. A kellö ritmust szeretném megtalálni, ne terheljem őket túl, ne rakjak túl nagy szabadságot a vállukra, amellyel még nem tudnak mit kezdeni, ismerjem fel, mikortól képesek több szabadságot több felelösséggel hordozni..."

A portfólió alkalmazásakor tehát a készítője aktívvá válik azzal, hogy maga dokumentálja a tanulási és fejlődési folyamatát, a megadott szempontok mentén értékeli önmaga és társai teljesítményét, a tanári reflexiók tükrében új célokat fogalmazhat meg.

A tudatosan és változatosan használt értékelési módszerek nem csupán a fenti célok elérését támogatják, hanem bővítik a jelöltek értékelési repertoárját. E rövid felvetésből is jól azonosítható azonban, hogy a képzőintézmények előtt még számos feladat áll e terén:

- a szakmai kompetenciák és sztenderdek azonosítása és tudatosítása az érintettekkel,

- a képzési folyamatba ágyazott fejlesztési folyamatok kidolgozása mind tartalmi, mind módszertani szinten,

- a sztenderdekhez kötött mérési, értékelési rendszer kidolgozása és bevezetése,

- $\quad$ s mindezekhez kötődően a hallgatói értékelési rendszer átdolgozása, a fejlesztő értékelés érvényesítésével.

A támogató értékelés szerepe a gyakorlatok során

A pedagógusképzés egyik kulcskérdése az elmélet és gyakorlat kapcsolatának szorosabbá tétele. Különösen megfontolandó az intézményi, a személyi szintü együttmüködés elősegítése az értékelési követelmények megfogalmazása és érvényesítése kapcsán. A gyakorlatok szerepét általában igen magasra értékelik a pedagógusjelöltek, ahogy ezt egy legutóbbi hazai kutatás is igazolta (N. Kollár, 2008). Ugyanakkor ezzel kapcsolatban meg kell jegyezzük, hogy a gyakorlatok mennyiségi növekedése, amely szinte minden felmérésben megfogalmazódik a hallgatók részéről, önmagában még nem garantálja az ott végezett hatékonyabb szakmai fejlesztés fejlődés biztosítását. Különösen élesen merül fel ez a kérdés a most induló 5. félévben teljesítendő gyakorló félévvel kapcsolatban.

A fejlesztő értékelés OECD által kiadott fogalmának két meghatározó eleme a gyakori, interaktív visszajelzés, illetve a diák aktív részvétele saját tanulási és így 
értékelés folyamatában is. Mindezt rávetítve a gyakorlatok kérdésre elengedhetetlennek tünik a mentori funkció értelmezése is. A mentor hatékony bástya lehet a szakma tanulásának értékeléssel történő támogatásában is. Épp ez az az elvárás, amely kirajzolódik a Tanárképzők Szövetségének 2009-ben elfogadott ajánlásában az 5. félévre vonatkozóan: ,,...Javasoljuk, hogy az 5. félév kezdeti idöszakában - a tanárjelölt és a mentor „ismerkedési” idöszakában - a mentor (a már kifejlesztett eszközök és módszerek segitségével, amelyek a mentorképzésben átadásra és kipróbálásra kerültek), a hallgatóval közösen mérje fel a hallgató kompetenciáit, illetve jelölje meg a kiemelten fejlesztendö kompetenciák körét. A mentor készítsen egyéni fejlesztési tervet, ami a félév munkáját orientálja. Az elöirások szerint, a fejlesztés igényei, illetve a mentor által javasoltak alapján jelöljék ki a hallgató által végzett tevékenységek körét. A munkát kísérje folyamatos, fejlesztö értékelés. A félév végén a hallgató képes arra, hogy elméleti felkészültségét a gyakorlattal ütköztesse, hogy az adott pedagógiai szituációkat értelmezze, gyakorlati megoldásokat keressen azokra, és végre is tudja hajtani. Legyen képes problémái megfogalmazására, tudjon pedagógiai alternatívákat felállitani. Fejlödjön önismerete, tudatosabban kötödjön a szakmájához, értö módon használja a szakmai nyelvet. A félév értékelése a mentor hatásköre, a fejlesztési tervhez kötödik..." (Györ, 2009.)

Számos kulcspontot rögzít ez az elvárás is, amely kapcsolódhat a fejlesztö értékelés témájához: fejlődési terv; portfólió. Az ajánlástól függetlenül is érdemes átgondolni, hogy a fejlesztő értékelés segítségével miképp támogathatók a hallgatók a gyakorlatokon szakmai fejlődésükben. Bár a Magyarországon bontakozó rendszer egyedi megoldásnak tünik, mégis sok tekintetben hasonlít más országokban megjelenő törekvésekhez, gyakorlathoz. A 5. féléves gyakorlat még az egyetemi kurzusok része, mégis huzamos ideig iskolában töltött időt jelent újszerü feladatokkal és kihívásokkal. Valószínüleg erre az időszakra nézve is értelmezhető lesz a pályakezdési sokk. A pályakezdés kapcsán ismert reality shock (Imre, 2004) egyik oka, hogy a szakmai pályafutását kezdő tanár gyakorta sem meglevő kompetenciáival, sem hiányosságaival nincs igazán tisztában, de önfejlesztésnek tudatos irányítása sincs gondolkodásának előterében. Épp ezért fontos, hogy vagy a képzés során megkezdett szakmai portfólió elemzésével vagy folytatásával segítsék a pályakezdőt. Angliában például a 2007 szeptemberétől induló Karrierkezdési és -fejlődési Profil (Career Entry and Developmnet Profile $-C E D P)^{5}$ program a tanári munka első évében támogatja a pedagógusokat különböző szempontrendszerekkel a tanárképzési tapasztalatok elemzésében és a pályára való tudatos felkészülésben (Kálmán és Rapos, 2007). A CEDP-ről szóló, on-line formában is elérhető szakmai segédanyagokban így fogalmaznak a minden valószínüséggel kezdetben bizonytalan olvasónak: „,...Minden elemzési ponthoz tartozik egy kérdéssor, amelynek segitségével átgondolhatja eddigi teljesitményét, valamint a jövőbeni tanulását és fejlödé-

\footnotetext{
${ }^{5} \mathrm{http}: / /$ www.tda.gov.uk/teachers/induction/cedp.aspx
} 
sét. A CEDP az ön profilja, öné a legföbb felelösség, hogy dolgozzon rajta. Azonban a tanitás együttmüködésen alapuló szakma, ezért a pedagógusképzés során az oktatói és gyakorlatvezetöje segitségével fogják megállapitani azt, hogy miben kell még fejlödnie és mire kell ügyelnie munkája során..."

A fejlődés megtervezése és kivitelezése ez pályakezdő szakaszban is önálló felelősségvállalás, együttmüködés eredménye, amely irányelvek a fejlesztő értékelés és később a pedagógiai munka alapját képzik majd. Lényeges azonban azt is látnunk, hogy ebben a fejlődési folyamatban egy támogató, értékelő személy segíti a jelölt munkáját. E tanulást támogató értékelésnek alapja minden esetben egy akcióterv és azt követő önelemző és támogató értékelés.

Az akciótervnek ${ }^{6}$ igen egyszerü, de annál következetesebben elemezhető részei vannak, amelyeket az 2. táblázat mutat be. Rendkívül fontos eleme az akciótervnek a célok tisztázása, aminek hangsúlyozottan a pályakezdők problémáira kell irányulnia, s egyben lehetővé kell tenni, hogy abban a jelölt építhessen az erősségeire. Segíti a folyamatot, ha a célok száma nem túl sok, javasolt kb. három és öt elem. A folyamat támogatásában kiemelt jelentőségü a folyamat elemzése, értékelése, amelynek egyik fő módszere a megbeszélés lehet a kezdő szakember és az értékelő személy között. Ezt a megbeszélést, illetve rendszerelemet szempontokkal is támogatják a programban (3. táblázat). Az akcióterv és annak elemzési szempontjai a most bontakozó rezidensképzéshez is adhatnak támpontokat a tanulást támogató értékelés szempontjából.

2. táblázat: Akcióterv az indukciós szakaszban

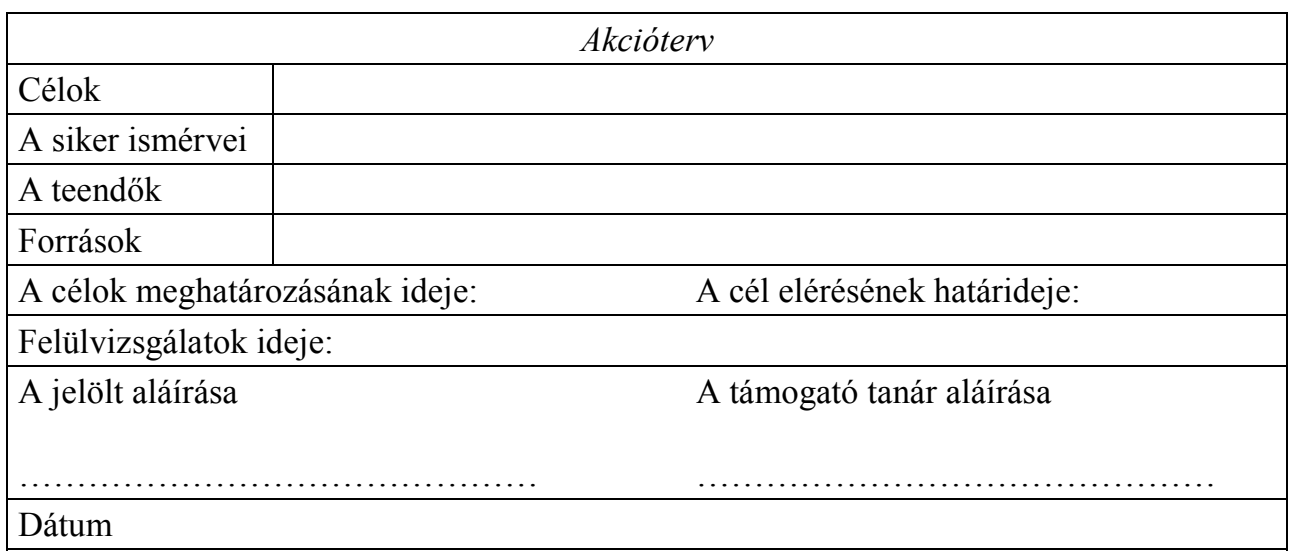

\footnotetext{
${ }^{6}$ A CEDP dokumentumokban leginkább az akcióterv kifejezést használják a szerzők. Céljai, szerkezete lényegében megegyeznek a korábban e tanulmányban alkalmazott fejlődési terv kifejezéssel.
} 
3. táblázat: Szempontok az akcióterv értékeléséhez

Gondoljon arra, hogy mennyire sikerült közelebb jutnia a céljaihoz az utóbbi hetekben.

Honnan tudja, hogy elörehaladt? Hogyan tudta megtenni ezt az elörelépést?

Melyek azok a szakmai fejlödési lehetöségek, amelyek a legnagyobb hatással voltak önre, és a tanítási gyakorlatára?

Miért segítettek ezek ennyire? Voltak olyan támogatott tevékenységek, segítségek, amelyek kevésbe segitették? Mit gondol, miért?

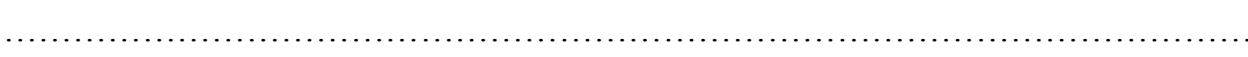

Vannak olyan célok, részcélok, ahol kevesebb elörehaladást mutatott?

Miért gondolja ezt? Mit gondol, miért történt ez?

Milyen további segítséget, támogatást gondol hasznosnak?

Mi segítené az eddigi eredményeire való épitést és a céljaihoz való közeledést?

Milyen új célokat kellene meghatároznia az elkövetkezö idöben?

Ezek vonatkozhatnak például:

- kulcsfontosságú pontokra, amelyeket korábban meghatározott, azonban nem sikerült elérnie;

- új, vagy váratlan prioritásokra;

- célokra, melyeket átvett egy korábbi akciótervböl.

Ezek miért fontosak önnek? 
Az egyéni fejlődési terven vagy akció terven túl érdemes még egy kitérőt tenni a portfólió és a hozzá kapcsolódó szakmai kompetenciák és sztenderdek szerepére. Az egyéni szakmai portfóliók, vagy, ahogy nemzetközi irodalmakban nevezik egyéni szakmai profilok kidolgozása olyan szakmai környezetben válik természetessé, ahol kidolgozott követelmények és azok mérhető szempontrendszere is ismert, s ezek képezik a szakmai továbblépés, önfejlesztés alapját. Ehhez természetesen meg kell adni a szakmai kompetenciák mérhető sztenderdjeit. Erre példa a Training and Development Agancy for School honlapján megismerhető szakmai sztenderd rendszer. A tanulmányban csupán az értékelésre vonatkozó részek kerültek kiemelésre. A teljes kompetencia- és a hozzá kapcsolódó sztenderdlista sok más elemet is tartalmaz, például kapcsolat a gyerekekkel és fiatalokkal; kommunikáció és együttmüködés másokkal; a személyes professzió fejlődése; tanítás és tanulás; egészség és jó közérzet. Ennek értelmében a szakmai tudás minden egyes területéhez meghatároztak alapszintü követelményeket, amit képesített tanári státuszhoz rendeltek (QTS). Majd a szakmai fejlődés jegyében további fejlődési szinteket határoztak meg (qualified teacher status; core; post threshold; excellent teacher; advanced skills teacher), s ezekre nézve megadták az adott szaktudás terén elérendő elvárásokat. Ezek és az itt ki nem hangsúlyozott követelményterületek szintekhez történő rendelése adja az adott karrier szint elvárható profilját.

A 4. és az 5. táblázatokban ${ }^{7}$ látható, hogy a sztenderdek meghatározásakor érvényesítették a szakmai fejlődés szempontját ${ }^{8}, \mathrm{~s}$ az értékelés tekintetében hangsúlyos szerepet kaptak a fejlesztő értékelésre jellemező, fent már bemutatott alapelvek.

Az angol pedagógusképzés számára kidolgozott minta erénye, hogy ösztönzi az önálló felelősség vállalását mind a saját, mind a tanulóik fejlődésének tekintetében, mind az élethosszig tartó tanulás jegyében; a partneri kapcsolatot az érintettek közt, az együttmüködést; és az egyéni utak elismerését. Formailag tömör és strukturált a rendszer. Jól követhetők az összetartozó tartalmi elemek és azok változása, elmélyülése, valamint a szakmai életúthoz tartozó kapcsolatuk (3. és 4. táblázat).

\footnotetext{
${ }^{7}$ A tda honlapján (http://www.tda.gov.uk/) elérhető szakmai sztenderdek közül a fejlesztő értékelés szempontjából lényeges elemek kerültek kiemelésre, $\mathrm{s}$ a fordításban helyhiány miatt ebből is csak a lényegi elemeket jelenítettük meg.

${ }^{8}$ A kidolgozott kompetencia elvárásnak megfelelően itt is 5 szintet különítettek el: qualified teacher status; core; post threshold; excellent teacher; advanced skills teacher.
} 
4. táblázat: Sztenderdek az értékeléshez, ellenőrzéshez - szakmai tudás

\begin{tabular}{|c|c|c|c|c|}
\hline \multicolumn{5}{|l|}{ szakmai tudás } \\
\hline $\begin{array}{l}\text { a képesitett tanári } \\
\text { státusz (QTS) } \\
\text { megszerzéséhez } \\
\text { (Q) }\end{array}$ & $\begin{array}{l}\text { minden } \\
\text { pedagógusnak } \\
\text { tudnia kellene } \\
\text { (C) }\end{array}$ & \begin{tabular}{|l|} 
az átlagnál \\
jobban teljesitoó \\
tanár \\
$(P)$
\end{tabular} & $\begin{array}{l}\text { kiváló } \\
\text { tanárokkal } \\
\text { szembeni } \\
\text { elvárások } \\
\text { (E) }\end{array}$ & $\begin{array}{l}\text { felsőfokú } \\
\text { szakmai } \\
\text { képességekkel } \\
\text { rendelkezö } \\
\text { pedagógusoktól } \\
\text { elvárható } \\
\text { (A) }\end{array}$ \\
\hline \multicolumn{5}{|c|}{ értékelés és ellenőrzés } \\
\hline \multirow{3}{*}{$\begin{array}{l}\text { Q11 Ismerje az általa } \\
\text { tanított tárgy tantárgyi } \\
\text { és tantervi értékelési } \\
\text { elöírásait, illetve azok } \\
\text { vizsgakövetelményeit. }\end{array}$} & \multicolumn{4}{|c|}{ C11 ugyanaz, mint Q11 } \\
\hline & & \multicolumn{3}{|c|}{$\begin{array}{l}\text { P3 Legyen felkészült és jól informált az általa } \\
\text { tanított tárgy tantárgyi és tantervi értékelési } \\
\text { elöírásaiból, illetve azok } \\
\text { vizsgakövetelményeiböl. }\end{array}$} \\
\hline & & \multicolumn{3}{|c|}{$\begin{array}{l}\text { P4 Legyen naprakész és jól informált } \\
\text { a különböző minősítési, képzési típusokból } \\
\text { és azok egyéni tanulói szükségletekhez kötött } \\
\text { alkalmazhatóságáról. }\end{array}$} \\
\hline $\begin{array}{l}\text { Q12 Ismerje az } \\
\text { értékelés különböző } \\
\text { megközelítési formáit, } \\
\text { illetve a fejlesztő } \\
\text { értékelés jelentőségét. }\end{array}$ & \multicolumn{4}{|c|}{ C12 ugyanaz, mint Q12 } \\
\hline \multirow{3}{*}{$\begin{array}{l}\text { Q13 Tudja, miképp } \\
\text { kell használni a helyi } \\
\text { és az országos mérési } \\
\text { adatokat saját tanítása } \\
\text { hatékonyabbá } \\
\text { tételére... }\end{array}$} & \multicolumn{4}{|c|}{ C13 ugyanaz, mint Q13 } \\
\hline & \multicolumn{4}{|c|}{$\begin{array}{l}\text { C14 Tudja, miként hasznosítsa a külső információforrásokat } \\
\text { abból a célból, hogy diákjainak alapos és konstruktív visszajelzést } \\
\text { adjon erősségeikről, gyengeségeikről, teljesítményükről, tanulási } \\
\text { és fejlődési folyamatukról, illetve miképp készítsen ezek mentén } \\
\text { fejlődési tervet számukra. }\end{array}$} \\
\hline & & & \multicolumn{2}{|c|}{$\begin{array}{l}\text { E4 Tudja miképp fejleszthető } \\
\text { az értékelési gyakorlat } \\
\text { hatékonysága egy } \\
\text { munkahelyen, illetve tudjon, } \\
\text { a tanulás-tanítás hatékonyabbá } \\
\text { tétele érdekében, valamint az } \\
\text { intézményi tanulás érdekében } \\
\text { statisztikai adatokat elemezni. }\end{array}$} \\
\hline
\end{tabular}


5. táblázat: Sztenderdek az értékeléshez, ellenőrzéshez, visszacsatoláshoz - szakmai képességek

\begin{tabular}{|c|c|c|c|c|}
\hline \multicolumn{5}{|l|}{ szakmai képességek } \\
\hline $\begin{array}{l}\text { a képesitett tanári státusz } \\
\text { (QTS) } \\
\text { megszerzéséhez } \\
(Q)\end{array}$ & \begin{tabular}{|l} 
minden \\
pedagógus- \\
nak tudnia \\
kellene \\
(C)
\end{tabular} & $\begin{array}{l}\text { az átlagnál } \\
\text { jobban } \\
\text { teljesitö } \\
\text { tanár } \\
(P)\end{array}$ & \begin{tabular}{|l} 
kiváló \\
tanárokkal \\
szembeni \\
elvárások \\
(E)
\end{tabular} & $\begin{array}{l}\text { felsöfokú szakmai } \\
\text { képességekkel } \\
\text { rendelkezö } \\
\text { pedagógusoktól } \\
\text { elvárható } \\
\text { (A) }\end{array}$ \\
\hline \multicolumn{5}{|c|}{ értékelés, ellenőrzés, visszacsatolás } \\
\hline \multirow{2}{*}{$\begin{array}{l}\text { Q26 } \\
\text { a) Hatékonyan alkalmazza } \\
\text { az értékelés, ellenörzés és } \\
\text { adatgyüjtés eljárásait. } \\
\text { b) Értékelje a tanulói } \\
\text { szükségleteit, hogy azok } \\
\text { alapján új, kihívást jelentő } \\
\text { tanulási célokat állítson. }\end{array}$} & \multicolumn{4}{|c|}{$\begin{array}{l}\text { C31 Hatékonyan használja fel a megfelelő megfigyelési, } \\
\text { értékelési, ellenőrzési és adatgyüjtési stratégiákat, melyek } \\
\text { alapján kihívó tanulási célokat állíthat és ellenőrizheti tanuló } \\
\text { tanulási folyamatát, elért teljesítményszintjét. }\end{array}$} \\
\hline & & & \multicolumn{2}{|c|}{$\begin{array}{l}\text { E10 Demonstrálja kiváló } \\
\text { képességeit. }\end{array}$} \\
\hline \multirow{2}{*}{$\begin{array}{l}\text { Q27 Adjon időszerü, } \\
\text { pontos és konstruktív } \\
\text { visszajelzést a tanulók } \\
\text { teljesítményérőll, tanulási } \\
\text { folyamatáról és } \\
\text { fejlödéséről. }\end{array}$} & \multicolumn{4}{|c|}{$\begin{array}{l}\text { C32 Adjon tanulókkal, kollégákkal, szülőkkel és } \\
\text { asszisztensekkel közösen időszerü, pontos és konstruktív } \\
\text { visszajelzést a tanulók teljesítményéről, tanulási folyamatáról } \\
\text { és fejlődéséről. }\end{array}$} \\
\hline & & & \multicolumn{2}{|c|}{$\begin{array}{l}\text { E11 Legyen kiváló abban, ahogy } \\
\text { támogatja a tanulókat, kollégákat, } \\
\text { szülőket, asszisztenseket } \\
\text { időszerü, pontos és konstruktív } \\
\text { visszajelzésekkel tanulói } \\
\text { teljesítményéröl, tanulási és } \\
\text { fejlődési folyamatáról, miközben } \\
\text { segíti diákjai fejlődését. }\end{array}$} \\
\hline \multirow{2}{*}{$\begin{array}{l}\text { Q28 Támogatást és } \\
\text { irányítást biztosít, hogy } \\
\text { tanulói maguk is } \\
\text { reflektáljanak, azonosítsák } \\
\text { a már megvalósult } \\
\text { eredményeiket } \\
\text { s a felmerülö tanulási } \\
\text { szükségleteiket. }\end{array}$} & \multicolumn{4}{|c|}{$\begin{array}{l}\text { C33 Támogatást és irányítást biztosít, hogy tanulói maguk } \\
\text { is reflektáljanak, azonosítsák a már megvalósult } \\
\text { eredményeiket. Pozitív fejlődési célokat ad, hogy tanulói } \\
\text { sikeres és önálló tanulókká váljanak. }\end{array}$} \\
\hline & \multicolumn{4}{|c|}{$\begin{array}{l}\text { C34 Az értékelést a tanítás részeként úgy alkalmazza, hogy } \\
\text { diagnosztizálja a tanulói szükségleteit, majd ez alapján } \\
\text { támaszt reális, de kihívó célokat a fejlesztés és a tanítás } \\
\text { megtervezésekor. }\end{array}$} \\
\hline
\end{tabular}


Összegzés

Abban az esetben, ha a szakmai önfejlödés és önfejlesztés igénye valóban beépül a pedagógusmesterségbe, akkor a tanulást támogató értékelésnek is nagyobb szerepe lesz. Ez komoly szakmai kihívás, de nehezen képzelhető el, hogy a diákjai fejlődését támogató értékelést hatékonyan és következetesen alkalmazza az a pedagógus, aki nem ért egyet annak elvi alapjaival, $\mathrm{s}$ azokat magára nézve nem tartja érvényesnek. A fejlesztő értékelés bevezetésének nehézségeire már Black és William is utalt (1999), amikor összegezték ez irányú tapasztalataikat. A pedagógusok

- szívesebben számszerüsítenek az értékelés során, ahelyett, hogy a tanulás minőségéről szólnának;

- többször adnak jegyet vagy besorolást az általuk rosszabbul teljesítőnek vélt diákoknak, mint, hogy tanácsokkal támogatnák a fejlődésüket;

- gyakran alkalmaznak összehasonlítást a tanulók közt, ami demoralizálja őket, és ezzel csökkentik a tanulók tanulmányi sikereit;

- nem ismerik eléggé diákjaik tanulási szükségleteit, szokásait, sajátosságait.

A fentiekben vázolt néhány felvetés csupán példa arra, hogy milyen szerepe lehet a fejlesztő értékelésnek a pedagógusképzésben. Mivel azonban a pedagógussá válás folyamata itt nem ér véget, ezért a képzőintézményeken túl az iskolákban is fontos volna átgondolni, miként támogathatnák a pedagógusok szakmai fejlődését a fejlesztő értékelés segítségével. A fejlesztő értékelés osztálytermi szintű bevezetése azonban nem csupán személyes döntés, intézményi támogatást is követel, így optimális esetben megjelenik az osztálytermi folyamatokon túl az intézmény által preferált értékelési elképzelésekben, az intézményértékelésben, így a pedagógusértékelésben is. Ez utóbbi lehetne a kulcsa a szakmai fejlődést egész életen át tartó támogatásának, amelynek módszertani megvalósításában akár a fent említett megoldások - például: egy szakmai portfólió - is szerepet kaphatnak. A kezdő pedagógusok számára pedig egy olyan intézmény adhat igazán támogató közeget a fejlödéshez, ahol a tanulás támogatása és élethosszig tartó volta mindenki számára elfogadott és kötelező.

\section{Irodalom}

Ajánlás a gyakorlati félévröl. Tanárképzők Szövetsége (2009), kézirat. Assessment Reform Group: http://www.assessment-reform-group.org/

Ayres, P., Dinham, S., Sawyer, W. (2000): Successful Senior Secondary Teaching. Australian College of Education, Canberra.

Black, P., William, D. (1998a): Assessment and classroom learning. Assessment in Education: Principles, Policy \& Practice, (5) 1, 7-76.

Black, P., William, D. (1998b): Inside the Black Box: raising standards through classroom assessment. Kings College, London. 
Black, P., William, D. (1999): Assessment for Learning: beyond the black box. Assessment Reform Group University of Cambridge, School of Education, Cambridge.

Bognár Mária (2006): A fejlesztő értékelés osztálytermi gyakorlata. Új Pedagógiai Szemle, 3. $s z .19-26$.

CEDP: http://www.tda.gov.uk/teachers/induction/cedp.aspx

Falus Iván (2005): Sztenderdek tanárok és tanárképzők számára. Pedagógusképzés, 4. sz. $143-146$.

Falus Iván (2006): A tanári tevékenység és a pedagógusképzés útjai. Gondolat Kiadó Budapest.

Falus Iván, Kimmel Magdolna (2009): A portfólió. Gondolat Kiadói Kör, Budapest.

Fejlesztő értékelés. A tanulást fejlesztö osztálytermi módszerek a középfokú oktatásban. (2005), Budapest, OECD, CERI, OKI, Budapest.

http://www.oki.hu/oldal.php?tipus=kiadvany\&kod=fejleszto

Golnhofer Erzsébet (2007): Az átalakuló pedagógusképzés és a neveléstudomány. Pedagógusképzés, 4. sz. 45-49.

Gustafsson, J. E. (2003): What do we know about effects of school resources on educational results? Swedish Economic Policy Review, (10) 2, 77-110.

Holt-Reynolds, D. (2000): What does the teacher do? Constuctivist pedagogies and prospective teachers'beliefs abuot the role of the teacher. Teaching and Teacher Education, (16) 1, 21-32.

Imre Nóra (2004): Pályakezdő pedagógusok a nemzetközi szakirodalomban. Pedagógusképzés, 3. sz. 79-96.

Kálmán Orsolya, Rapos Nóra (2007): Kellenek-e alapelvek a pedagógusképzés átalakításához. Pedagógusképzés, 4. sz. 23-42.

Lénárd Sándor (2009): Ajánlás a tanári képesitö vizsgán alkalmazott értékelö portfólióhoz. Munkanyag.

Lénárd Sándor, Rapos Nóra (2009): Fejlesztő értékelés. Gondolat Kiadói Kör, Budapest.

Lingard, B., Martino, W., Mills, M., Bahr, M. (2002): Addressing the Educational Needs of Boys: Strategies for Schools and Teachers. Commonwealth Department of Education, Science and Training, Canberra.

Nagy Mária (2004): A pályakezdés mint a pedagógus-képzés középső fázisa. Educatio, 3. sz. $375-390$.

4. számú melléklet a 15/2006. (IV. 3.) OM rendelethez. www.okm.hu

N. Kollár Katalin (2008): Pedagógusok pályaképe, a tanárképzéssel kapcsolatos elégedettségük és nehézségeik. Pedagógusképzés, 4. sz. 7-34.

Recent Education Policy Developments in OECD Contries. Educatoin Policy Analysis 2003, EOCD, Paris.

http://www.oecd.org/document/14/0,3343,en_2649_39263231_17735886_1_1_1_ $1,00 . \mathrm{html}$

Richardson, V. (Ed., 1997): Constructivist Teacher Education. Falmer, London.

Sztenderdek: http://www.tda.gov.uk/teachers/professionalstandards/standards.aspx

Teachers Matter: Attracting, Developing and Retaining Effective Teachers. OECD 2005. 
The Quality of Teacher, Policy paper, ATEE, 2006.

http://www.atee1.org/uploads/kennisbank/quality_of_teachers_atee_def.pdf

Training and Development Agency for School: http://www.tda.gov.uk

Vidákovich Tibor (2005): Fejlesztő értékelés: A formatív értékelés újrafelfedezése.

(ftp://ftp.oki.hu/download/hirek/hirek-konferencia-20050929/abstract-vidakovicht.pdf) 